This item was submitted to Loughborough's Research Repository by the author.

Items in Figshare are protected by copyright, with all rights reserved, unless otherwise indicated.

\title{
Explaining the choice between alternative insolvency regimes for troubled companies in the UK and Sweden
}

PLEASE CITE THE PUBLISHED VERSION

PUBLISHER

(C) Springer-Verlag

LICENCE

CC BY-NC-ND 4.0

REPOSITORY RECORD

Cook, Gary, and Keith Pond. 2019. "Explaining the Choice Between Alternative Insolvency Regimes for Troubled Companies in the UK and Sweden”. figshare. https://hdl.handle.net/2134/1210. 
This item was submitted to Loughborough's Institutional Repository by the author and is made available under the following Creative Commons Licence conditions.

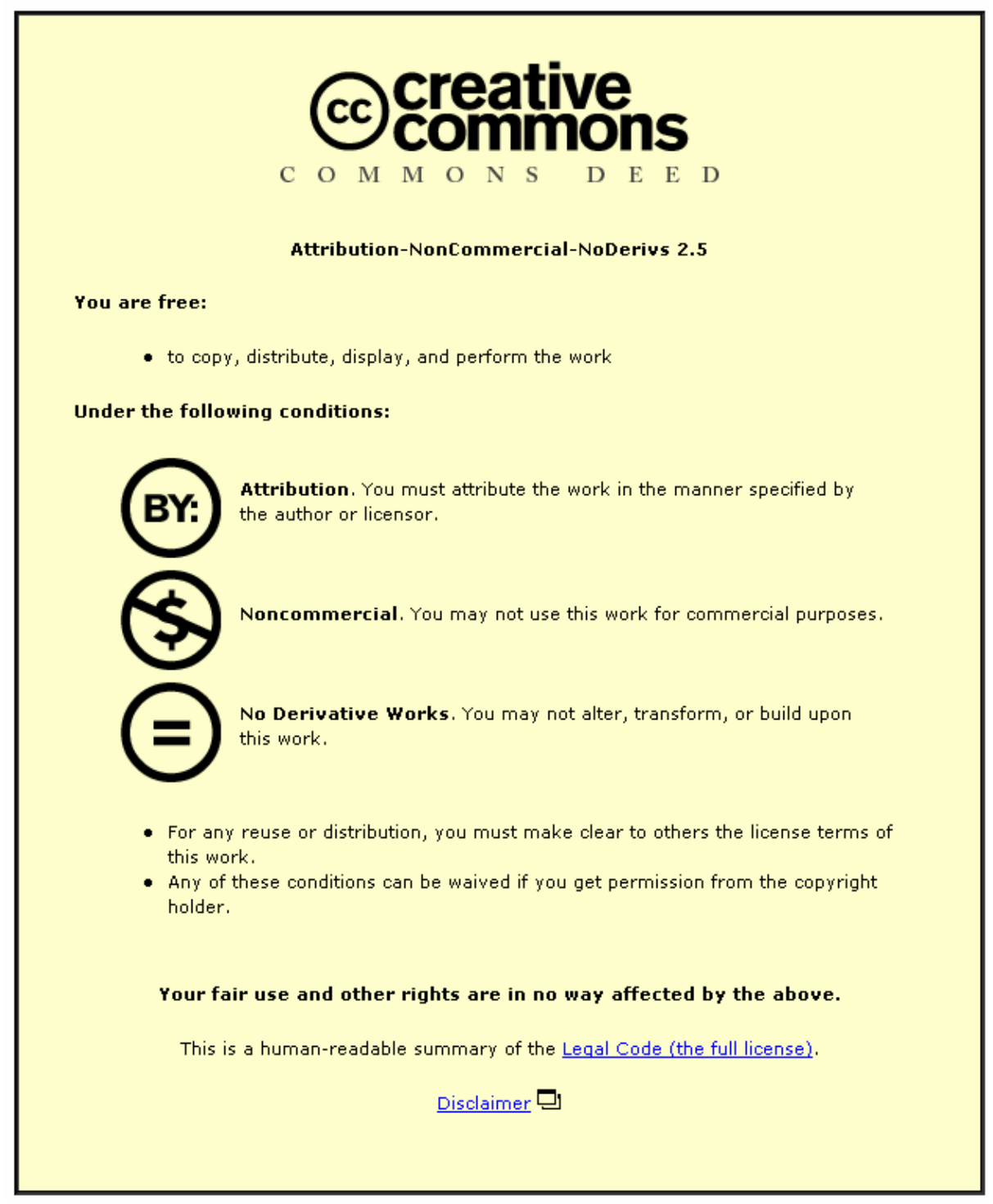

For the full text of this licence, please go to: http://creativecommons.org/licenses/by-nc-nd/2.5/ 


\title{
드 Loughborough University
}

Explaining the Choice between Alternative Insolvency

Regimes for Troubled Companies in the UK and Sweden

\author{
Gary Cook \\ Senior Lecturer in Applied Economics, \\ The University of Liverpool Management School \\ Keith Pond \\ Senior Lecturer in Banking and Economics, \\ The Business School, Loughborough University
}

Address for correspondence:

Dr Keith Pond

The Business School

Loughborough University

Loughborough

LE11 3TU

+44 (0) 1509223290

K.Pond@lboro.ac.uk 


\section{Abstract}

Explaining the Choice between Alternative Insolvency Regimes for Troubled Companies in the UK and Sweden

Over the past 20 years UK and Swedish insolvency law has moved in the direction of company rescue rather than enforcing secured creditor priority. However, both countries show a low take up rate of rescue procedures.

This paper uses a cost-benefit approach to examine the choices faced by key stakeholders using the now conventional transaction cost paradigm. The paper argues that it is predominantly the ex post indirect and time costs which explain the poor take up of customised rescue procedures. In both countries the ex ante cost of delay in filing also presents a tough challenge not fully addressed by policymakers.

Keywords:

INSOLVENCY, UK, SWEDEN, COST-BENEFIT,

RESCUE, CREDITOR

JEL Classification

K22 


\section{Introduction}

A common trend around the world has been the reform of bankruptcy law to promote corporate rescue (OECD 1998, Audretsch 2002, European Commission 2000, 2003, 2004). In terms of promoting a dynamic market economy, bankruptcy rules need to strike a balance between encouraging new firm formation through reducing the fear of failure and yet quickly and efficiently eliminating non-viable firms. Both the UK and Sweden are examples of countries which have changed their bankruptcy laws in partial emulation of Chapter 11 in the U.S.A., in order to promote corporate rescue and entrepreneurship. In both cases the take up of these bespoke rescue regimes has been very low. This paper addresses the question - why? The paper will also touch on the broader question of whether the current bankruptcy regimes maximise overall welfare, which entails consideration of the ex ante effects of bankruptcy resolution on terms and availability of credit and the incentives of firm to either under- or over-invest.

The law has an important influence on how financial distress will be tackled in two fundamental ways. Firstly, the legal framework has an influence on the costs and benefits of formal rehabilitation and liquidation procedures and therefore also on their relative attractiveness (IMF 1999, Claessens \& Klapper 2002). Secondly, particularly where insolvency law is pro-creditor, the threat of a formal insolvency procedure may improve incentives for an informal workout (IMF 1999, Claessens \& Klapper 2002). The law also influences power over regime selection and management. In practice the efficiency and effectiveness with which the law is implemented also makes a difference, 
however this does not appear to be a significant consideration in either country.

The analysis concludes that the legal structures in the UK and Sweden bear heavily on the decision-makers but cannot fully explain the low incidence of rescue in each country. New legislation in the UK and possible reform in Sweden is reviewed in the light of this analysis and implications of change in the law outlined. Much of the current debate about promoting rescue of distressed firms is focused on saving the company, a specific legal entity. This paper concludes this emphasis is misguided. What matters more, from an economic perspective, is business survival whether or not the company is preserved.

\section{Alternative regimes}

Legislation in 1986 (Insolvency Act) in the UK and in 1996 (Business Reconstruction Act) in Sweden was designed to provide troubled companies with an alternative to liquidation of available assets and an end to the company and business. "Rescue" schemes had been available in the past in both countries but uptake had not been good since they were, largely, informal and lacked court protection. Instead, the practical impact of insolvency law had been to strengthen the hand of senior and secured creditors, typically banks. The Enterprise Act (2002), that came into effect in the UK on 15 September 2003 in respect of corporate entities aimed to make the "rescue" regimes administratively easier and also to promote a more 
collective approach to the resolution of financial distress. Table 1 summarises the various regimes available in the UK and Sweden.

\section{INSERT TABLE 1 ABOUT HERE}

\subsection{Formal rescues}

The UK reforms in 1986 allowed troubled companies to reach a binding composition with creditors under the court validated Voluntary Arrangement (VA) scheme. In almost all cases this involves both deferred payment and debt forgiveness. VAs can be arranged within the protection of an Administration Order $(\mathrm{AO})$ and could allow a business to continue to trade or to hive-down free from the threat of creditor action. The time-limited protection afforded by an $\mathrm{AO}$ amounts to a legal stay on the actions of secured and unsecured creditors including Hire Purchase creditors. Additionally an Administrative Receiver (AR) under a qualifying floating charge cannot be appointed once the AO has been granted, although secured creditors enjoyed the inalienable right to appoint an $A R$, frustrating an application for an AO. Floating charges dated after 15 September 2003 only have the right to appoint an Administrator. Since this is an "out of court" procedure, however, the key difference between this and the pre-15 September position is that the Administrator is responsible to all creditors whilst the AR was responsible only to the appointing creditor. 
Voluntary Arrangements could also be agreed without an $\mathrm{AO}$, although these are rare. The Insolvency Act 2000 in the UK did allow a similar legal moratorium to protect a VA scheme without resort to an AO but only for "small" companiesii. Uptake of this has been very poor.

Significantly, the existing management of the troubled business retains control in a VA under the supervision of a licensed insolvency practitioner (IP). Where an $\mathrm{AO}$ is in force, however, incumbent management surrenders control to the Administrator. Another sometimes-important distinction between a VA and an $\mathrm{AO}$ is that firms in administration must give notice of that fact on invoices, emails and letterheads. Creditors are assured that their priority level will be maintained although, clearly, the risks of continuing to trade need to be weighed carefully. Where VAs are used, there is considerable evidence that they have superior rates of business and job preservation as well as superior recovery of debt to all classes of creditor (R3 2000, 2004, SPI 1996a, 1996b, 1997, 1999). Clearly there is a selection bias in that only the most promising cases will get as far as a VA, nevertheless, this track record indicates that reconstruction under formal rescue procedures can work.

Under The Enterprise Act 2002 floating charge ${ }^{\mathrm{iii}}$ holders do lose some priority in distributions where their charge is dated after 15 September $2003^{\text {iv }}$. Together with a downgrading of the priority of Crown creditors ${ }^{\vee}$ more funds should be available to unsecured creditors. Whilst there is no UK study of the impact of this change the Finnish experience, following a similar shift in priorities in 1993, suggests a straightforward re-distribution of funds from 
secured to unsecured creditors without increases in bankruptcy costs (Bergström et al., 2004).

VA, AO and AR appointments are "out of court" procedures, minimising the influence of the bankruptcy registrar/judge considerably. This typifies the contract-based approach of the UK (Franks \& Sussman 2003), where courts are not minded to interfere in private contracts unless there has been misfeasance.

Swedish legislation provides for a similar regime whereby directors of failing businesses can apply for court protection against creditor action whilst putting a rescue plan together. Court protection comprises a moratorium on civil and debt actions and enforcement, including Retention of Title (ROT) claims. Creditors rights are safeguarded, including those with chattels mortgages and liens (the moratorium does not apply to them).

Swedish Reconstructions replaced the earlier Compositions, available since 1970. Under a reconstruction super-priority is granted to lenders willing to extend new credit. In this way the law can encourage rescue. In addition, post-reconstruction debt is recoverable from the company whilst prereconstruction debt is subject to the moratorium. As in the UK the directors remain in control of the reconstructed company but under the supervision of an insolvency professional. 
The power of the insolvency professional is somewhat weaker than in the UK as only "directions" can be issued to company directors. Failure to follow the practitioner's directions can result in immediate bankruptcy - a punitive sanction that is little used in practice. Further supervision is provided by a creditors' committee of three members, including one employee (Persson, 2003). The reconstruction period is an initial three months, extendable in three month periods to a maximum 12 months.

In this paper we concentrate on Swedish Reconstruction and the UK rescue schemes of AO and VA, acknowledging that the AR procedure is still available but in a decreasing number of cases.

\subsection{Liquidation schemes}

The default position in all insolvency regimes is the winding-up of a company. Liquidation is always terminal for a company but businesses can survive in whole or in part as they are sold to new owners. Compared to other regimes, liquidation is less amenable to the preservation of the business as a going concern (Franks \& Torous 1992). For example, compared to a liquidator, the administrator has powers to cancel contracts and some liabilities can be stayed during the period of administration. Under the AO the administrator is not personally liable for liabilities taken on after appointment.

Thorburn (2000) spells out some key institutional features of the Swedish bankruptcy system. Management is removed from control directly on filing. It 
is important to set against this the fact that in Thorburn's sample, $54 \%$ of going concern sales were to incumbent management. There is an automatic stay on creditors' actions. Many bankruptcy sales are by auctions which are ascending and payment must be in cash. Whilst provision for new debt with superpriority exists, in practice it is very rare. Any new debt tends to be in the form of trade credit. The bankruptcy trustee is under a clear obligation to act in the interests of all creditors, who are paid out of the cash proceeds of the auction according to absolute priority. The nature of auction pre-packs in Sweden is that a sale for cash is agreed in advance, but since the cash proceeds are insufficient to satisfy all claims, the firm must enter bankruptcy. The great advantage of pre-packs is lower costs. Thorburn finds that the mean time spent in bankruptcy in Sweden is 2.4 months, much lower than the time typically spent in Chapter 11, where estimates indicate an average of around 2 years, as is also the case in UK CVAs (Cook et al. 2003).

\subsection{Informal rescues}

The extent of informal business rescue is difficult to ascertain since secrecy often surrounds and protects individual cases. The "London Approach" (Kent, 1994 ) is also responsible for a small number of large-scale rescues. One of the advantages of the approach is that company problems can be kept secret to some extent, thus helping avoid defections of suppliers and customers whose confidence in the distressed company might otherwise be undermined. 
It is important to note that a substantial amount of reconstruction in the UK has occurred within banks for a number of years (Wheatley, 1984). Franks and Sussman (2003) provide a highly revealing insight into the activities of banks which have developed "intensive care" units to try and help financially distressed companies. Companies experiencing financial problems are passed to the unit who work with them to try and stabilise the situation. This procedure is more complex for multi-banked companies with dispersed public debt since co-ordination between lenders is needed. In Franks \& Sussman's study around $75 \%$ of companies subject to "intensive care" avoid formal insolvency procedures. Rescue is often accompanied by management changes, asset sales and new finance and or increased personal guarantees by the directors. During the period in "intensive care" the debt burden shifts from the bank to trade creditors. This effect is larger when the rescue attempt fails and formal insolvency ensues. When the result is formal insolvency, average recovery rates are $77 \%$ for the bank, $27 \%$ for the preferential creditors and virtually nil for unsecured creditors. This informal reconstruction again has the virtue of secrecy. Adverse selection suggests that firms reaching formal insolvency will tend to be the less promising cases. This needs to be borne in mind when evaluating the apparent bias towards liquidation in official statistics. In addition it may well be the case that banks pushing firms towards liquidation may be doing so on the basis of private information and benefits.

In Sweden informal rescue is termed Ackord and is championed by a trade body, Ackordscentralen, which has 5 offices around Sweden including a head 
office based in Gothenberg (Cook, 2001b). Ackordscentralen acknowledge, however, that their main work is in bankruptcy since most failing companies leave matters too late for rescue to be viable.

\subsection{The incidence of rescue}

Neither VAs nor AOs recorded substantial numbers of cases until 1994. During 1990 - 1992 liquidation was the preferred route for the large number of insolvent companies suffering from the UK recession. Numbers of UK corporate insolvencies are shown in Table 2 and indicate that, in 1995, rescue regimes accounted for $20.7 \%$ of insolvency cases. This had fallen by 2004 to $13.6 \%$ largely due to the rapid decline in numbers of ARs. During these same years the actual numbers of AOs and CVAs grew.

\section{INSERT TABLE 2 ABOUT HERE}

In Sweden the pattern of usage of winding up and rescue mechanisms was remarkably similar to that in the UK between 1995 and 2004. Notwithstanding the change in the law in 1996 numbers of rescues and reconstructions have represented under $1 \%$ of insolvency cases. In 1991 there were 938 compositions but this represented only $1.86 \%$ of all cases. At the time Sweden was, itself, experiencing recession and a banking crisis, features that 
tend to mitigate against rescue. Since 1995 the numbers of insolvencies has fallen to a fairly consistent level as shown in Table 3.

\section{INSERT TABLE 3 ABOUT HERE}

\section{Cost-benefit analysis}

\subsection{The Transaction Cost Approach}

A variety of direct (e.g. fees to legal and financial advisers) and indirect costs (spelled out in detail below) of bankruptcy have been identified which are borne by financially distressed companies, which may be considered under the overall umbrella of transaction costs. This transaction cost perspective has become the dominant framework for explaining the choice between alternative modes of resolving financial distress, creditors being assumed to opt for the regime with the highest expected net returns (Gilson 1997, Gilson, John \& Lang 1990, Wruck 1990). There are two important findings in the literature regarding these costs. Firstly the indirect costs are consistently estimated to be larger than the direct costs. Secondly, that costs of both kinds are much greater in a rescue scenario than informal workouts. Indirect costs, in particular are a direct function of time spent in the procedure and Chapter 11 is consistently shown to be a more drawn out procedure than 
workouts. In general expected time in the regime will be a fundamental influence on choice given this connection with indirect costs.

Most attention in the literature has been given to ex post indirect costs, i.e. those emerging once financial distress has manifested and resolution with creditors is underway. Increasing attention is being paid to ex ante indirect costs, which refers to the unfavourable impact on the availability or terms of finance even before formal insolvency. This is based on creditors' fears of costs should insolvency occur and as incentives to over- or under-invest prior to bankruptcy. These ex ante costs, like the ex post, are apt to be influenced by the particular nature of the insolvency regime in place. Problems of underand over-investment also arise ex post and may also affect the availability and terms of credit ex ante. For clarity these two types of indirect cost will be considered in turn, together with consideration of factors which might influence how large they will be. Among the important ex post indirect costs are the following:

3.1.1 Diversion of management time, which can result in weaker competitive performance and failure to exploit investment opportunities (Gilson, John and Lang 1990, Kaiser 1996, Belcher 1997, Wruck 1990). There is no evidence this is a material consideration in either the UK or Sweden, therefore will not be discussed further.

3.1.2 Under- or over-investment ex post. Under-investment is the inability to raise sufficient finance (Gilson, John \& Lang 1990, Gertner \& Scharfstein 
1991, Senbet and Seward 1995, Kaiser 1996). The availability of debtor-inpossession financing is important here as most firms entering insolvency are cash deficient ${ }^{\mathrm{vi}}$. Under-investment is more likely in two, non-mutually exclusive circumstances. Firstly the firm may have a substantial debt overhang, in which case shareholders cannot envisage a large enough return to yield themselves a positive expected return on any new funds invested. The same would apply to any new source of finance unless super-priority were available seeing them paid ahead of existing debt. The second scenario is where debt maturity is short, which would include cases where creditors could enforce security immediately, possibility which can be forestalled by the availability of an effective moratorium. The disincentive to invest here is that shareholders must bear all the risk of the investment since they must not only provide the incremental funds required for the investment but also "buy out" existing debtholders. This can mean even a positive net present value project will have a negative expected return for shareholders (see Chen et al. 1995 for details).

Under-investment may also result from exposure to legal liability. Where firms or their advisers may be open to attack for trading on, then this may create a tendency towards early liquidation.

Over-Investment ex post (as well as ex ante as discussed below), can result from shareholders and directors having an incentive to gamble with creditor's money in projects with positive expected returns to shareholders but negative expected net present values (Chen et al. 1995, Keasey \& Watson 1994). A particularly egregious example in Chapter 11 is Eastern Airlines (Weiss \& Wruck (1998). 
3.1.3 Loss of customer and supplier goodwill, which can impose penalties of lost sales, reduced value of inventories and higher costs (Senbet and Seward 1995, Kaiser 1996, Belcher 1997). The ability to maintain supplier and customer goodwill will be influenced by whether or not the firm's problems can be hidden and how the directors have behaved, particularly towards suppliers, in the run-up to bankruptcy. Loss of employee goodwill will also limit choices (Senbet and Seward 1995)

3.1.4 Bargaining costs (Senbet and Seward 1995, Kaiser 1996). Reorganisation plans have implications for the amount of value created for distribution and the way in which it is distributed. Coalitions of creditor interest may form to maximise returns from the reorganisation process even if the overall outcome is inefficient. Moreover, value can be destroyed in the process of resolving conflicts within and between creditor groups. Bankruptcy law can reduce these costs by narrowing the bargaining space (Brown 1989).

Bargaining costs among creditors are likely to increase with the complexity of the firm's capital structure (Senbet and Seward 1995). The problem of creditor co-ordination is central to the choice of regime. Trade creditors are widely seen as presenting particular problems as they tend to be dispersed, heterogeneous and can eschew economic rationality (Gilson 1996). The more concentrated debt, the stronger the predisposition for a private workout. The key reason here is that it is easier to gain required creditor support. This is amplified if debt is in the hands of a bank (see Claessens \& Klapper 2002 for 
evidence) as banks are seen as sophisticated, rational creditors. Secondly, banks are viewed as having superior monitoring abilities and therefore bank support signals the fact that the firm is viable as a going concern. Conversely, where debt is held by many agents a formal regime is required to enforce coordination and prevent perverse actions such as creditor runs (Gertner \& Scharfstein 1991, Mooradian 1994). Majority rules which allow dissenting minorities to be bound into the reorganization plan considerably lessen the creditor co-ordination and holdout problems. Bolton and Scharfstein (1996) in particular derive the result that it is better for firms likely to experience liquidity defaults (as opposed to strategic defaults) to contract with a single debtholder to avoid ex post inefficiencies of uncoordinated creditor action. The result might be either a smoother liquidation yielding higher value than in an "asset grabbing" scenario or a greater likelihood of a successful reorganization for economically viable firms. This contrasts with the superior debt bonding properties of dispersed debt holdings (Hart \& Moore 1998).

3.1.5 Other sources of indirect costs and value erosion ex post include:

(a) Asset sales where "fire sale" prices prevail. Intangible assets can be particularly harshly discounted (Gilson, John \& Lang 1990).

(b) Poor quality management remaining in control, especially where management weaknesses have been a source of failure (Hotchkiss 1995).

(c) Lack of legal flexibility (Wruck 1990) or delay (Baird 1986), where formal court leave is required. 
(d) Subsidy and fiscal regimes where, for example, tax losses can be carried forward under reorganisation (White 1989) and interest obligations cease.

\subsection{Ex Ante Costs of Bankruptcy}

Hansen \& Thomas (1998) identify four ex ante costs which may be associated with a particular bankruptcy regime.

1. The punishment effect refers to the problem that managers may not have the right incentives to act efficiently if they expect lenient treatment in bankruptcy.

2. The gambling effect recognises that some managers expect to be dealt with harshly in bankruptcy so have an incentive to take risks to achieve survival (see also Bowman 19801982 and Kahneman \& Tversky 1979).

3. The delay effect refers to the management fear of replacement within a bankruptcy procedure. This will delay filing and erode value. Highly leveraged firms may file earlier as distress becomes apparent more quickly, in part due to tighter monitoring by debt holders. Restructuring in a workout may also be more likely, since early attention to problems preserves value (Chatterjee et al. 1996)

4. Errors in reorganization or liquidating the wrong firms and violations of creditor priority (Senbet and Seward 1995, Webb 
1991) destroy value for creditors and cognisance of this risk may distort the price and availability of credit ex ante.

Indirect costs ex post or ex ante are at the heart of any debt resolution scheme and are subject to many variables. The firm specific variables range from the quality of the management, the degree of leverage and the tangibility of assets as well as the number and mix of creditors. External variables include the legal system, court processes and the availability of subsidies.

\subsection{The Case for Auctions.}

There are a number of basic arguments against reorganisation and in favour of liquidation via cash auctions, the key feature of bankruptcy in Sweden. These concentrate on the ex-post costs reviewed above and include costs of delay and negotiating time, small scale violations of priority (that can lead to ex ante and ex post distortions of credit availability (Weiss 1990). In addition, auctions provide a market for corporate control which can discipline inefficient management (Eckbo and Thorburn 2003, Hansen \& Thomas 1998). At the same time, there is no evidence that auctions will lead to inefficient closure of viable businesses. Lastly, auctions provide a real valuation of the assets which creditors may generally prefer to a hypothetical valuation (Baird 1986).

Stromberg (2000) argues that the problem of specific assets leading to underpricing in auctions may not be as serious as has been suggested because incumbent managers will have an incentive to bid for the assets themselves since there is a synergy with their own specific human capital. Sale-backs to 
incumbent management were also common in UK liquidations under receivership (Franks et al. 1996) and are becoming so under post 2003 administration orders.

Counterarguments to the desirability of auctions have been made by Easterbrook (1990). Central to Easterbrook's argument is the idea that if auctions had efficiency advantages, then firms would resort to them more readily and avoid formal insolvency or would lobby for formal procedures to be changed in favour of auctions. To be efficient, auctions should be placed in the hands of those who will be residual claimants, yet this is hard to determine and may alter over time as value is eroded in a failing company. Finally, Easterbrook argues that auctions are likely to lead to underpricing of assets, eroding creditor value. Hansen \& Thomas (1998) point out a standard result in auction theory (Vickrey 1961) that the expected value in an auction will be less than either the true value of the asset or the winner's maximum valuation of the asset. The greater the uncertainty over the true value of the assets the worse this problem becomes.

The remainder of this paper reviews the key UK and Swedish liquidation and reorganization regimes in the light of the above analysis. 


\section{The choice in the UK}

A variety of observable factors regarding the company may help distinguish which type of firm is likely to be placed in which type of insolvency regime. Standard financial ratio tests should provide some clue as to which firms are likely to be in a recoverable position, however accounting ratios have limited value in making genuinely ex ante judgements about which companies will survive and which will fail (Hamilton et al. 1997, Piesse and Wood 1992). The problem with such arbitrary accounting criteria is that they cannot distinguish between firms which are purely in financial distress and those which are also in economic distress. What is relevant but harder to assess are the reasons for failure, the quality of its management and the robustness of its reconstruction plan. In addition, information asymmetries make it harder to assess the prospects of small firms, not least since they tend to keep poorer accounting records (Nayak and Greenfield 1994). This information asymmetry in respect of SMEs is mitigated by the ability of banks to monitor and their incentives to do so.

Some other factors specific to the individual case will also bear on the decision whether or not to support reconstruction, including the complexity of the capital structure and the prospects of garnering sufficient creditor support. The longer the proposed reconstruction, the lower the chances of support. Both the Swedish Business Reconstruction Act and Administration procedures under the UK Enterprise Act 2002 effectively rule out cases where reconstruction will take longer than a year, although there is provision for 
extensions in exceptional circumstances. Companies with high realisable asset values may be less likely to achieve support for a rescue regime because they are worth more dead than alive to secured creditors. However, this does not preclude sale as a going-concern. Assessing how these company-specific factors affect the chances of a firm being placed into a particular insolvency regime is beyond the scope of the current paper.

A final consideration is the process whereby the decision is made. In both countries banks have a strong de facto power to direct debtors under the threat of liquidation. In the UK the Insolvency Practitioner also has an important influence in situations where they are approached by the directors of a distressed company.

\subsection{Direct costs}

In general these are not large given minimal court involvement, especially post Enterprise Act 2002. prior to this legal costs were a disincentive to AO use for smaller firms.

Banks do not appear to be particularly vigilant in keeping down the direct costs of bankruptcy. Indeed comparing with Thorburn (2000), Franks \& Sussman (2003) claim that Bank 1 in their sample had direct costs as a proportion of the total amount recovered $40 \%$ higher than in Swedish bankruptcy auctions and for Bank 2 in their study they were roughly twice as high. Direct costs in general are regressive and in some small firm cases will exhaust available funds. 
There is little doubt that banks continue to enjoy significant powers in insolvency even post Enterprise Act. Although the figure varies widely among individual providers, banks supply around $40 \%$ of all SME debt (Franks and Sussman, 2003). Banks also typically have very strong creditor seniority by virtue of fixed charge security and floating charge benefits, including rights of appointment in the event of financial distress. High recovery rates for the bank and low recovery rates for other creditors reveals that banks rarely make concessions to debtors. This is evidence of "lazy" monitoring, against which there is clear evidence that banks do monitor and do attempt to address concerns through placing distressed firms in "intensive care" units.

\subsection{Indirect Costs}

\subsubsection{Ability to raise finance}

The overriding expectation of an $\mathrm{AO}$ is that trading will be continued, at least in the short term. The Administrator has wide powers under The Insolvency Act 1986 (Schedule 1 as amended) to carry on the business of the company, to raise or borrow money and grant security over the company's property. Creditors dealing with the company post-appointment are informed that the Administrator has responsibility for debts but is indemnified by the company assets. By contrast no such powers are enjoyed in its sister rescue procedure the CVA, which has been a long-standing criticism of the procedure.

The issue of raising additional finance does not arise in liquidation, since the issue is simply to raise funds by asset sales and disburse them in priority 
order. Nevertheless, liquidation can remove the debt burden where a profitable core is sold in whole or in part.

The problem of financing working capital is one which causes substantial practical difficulties in CVAs. By definition, the firm starts off in a weak financial position and then will be required not only to make payments into the creditors' fund out of cash flow but must also avoid any new debts not covered by the stay on creditor actions. The longer the proposed duration of the CVA, the worse this problem becomes. By comparison with this long uphill struggle, cutting the firm's losses and buying the business back via liquidation or "pre-pack" under an AO may seem very preferable.

\subsubsection{Ex post under- or over-investment.}

The strongly creditor-oriented system in the UK means that there is no systematic distortion towards over-investment in the bankruptcy regime. Some investment in distressed companies will result in dissipation, yet this simply reflects the irreducible risk attending any commercial investment.

Kahl (2002) modelled the bank's decision to support a restructuring which captures some important features of the CVA, in particular that it may provide a valuable "real option". Creditors face a problem when a firm enters financial distress in determining whether the firm is viable or should be liquidated ${ }^{\text {vii }}$. Kahl argues that if creditors were confident in the future prospects of the firm then the most efficient course of action would be to convert debt to equity and allow the firm to trade on free from debt overhang. Retaining debt claims, 
while it hinders the firm, can nevertheless be a rational strategy for creditors. Retaining debt claims gives creditors the outside option of liquidating the firm if it does not recover. The model also shows that it may be rational for creditors to continue to support the distressed firm even if the firm defaults on its debt repayments during the restructuring. The CVA proposal can commit the distressed firm to a schedule of dividend payments into a creditors' fund and if these payments are not kept up the supervisor is empowered to petition for the winding up of the firm. Alternatively the supervisor can propose an amendment to the original plan incorporating an extension of the repayment term and a reduction in the amount of debt recovery. Provided the required majority vote is obtained the CVA will continue.

CVAs also mitigate the under-investment problem through debt forgiveness which can help address the disincentive from the equityholders' point of view of a substantial debt overhang.

Until The Insolvency Act 2000 UK companies wishing to use the VA procedure could not protect themselves from unilateral action by creditors without, first, appointing an administrator. For small companies, in particular, this was too costly, leaving liquidation as the only realistic option. Amendments to the VA procedure, which came into effect in 2002, allow "small companies" to be protected by a moratorium on all legal action against them. Take up of this option has been extremely poor. Reasons advanced by the UK IPs interviewed being the complexity of the legislation and the 
perceived exposure to legal liability involved in being required to vouch for the viability of the reconstruction.

The practical importance of the absence of a moratorium in a CVA is open to question in the light of Franks and Sussman's (2003) evidence that creditor runs are rare. Nevertheless, the risk is important, as it has acted as a deterrent to IPs putting in the groundwork necessary to prepare a case for a CVA.

\subsubsection{Vulnerability to legal liability.}

This may dispose both banks and insolvency practitioners to favour a quick winding up of the company to avoid potential liability from trading on. Franks and Torous (1992) report a strong impression from IPs that there is less risk from a rapid sale of the business than from raising new funds to keep the company afloat. Whilst the IP is indemnified from the assets of the business such assets may not be valuable enough to support the risk. Potential liability as a shadow director may inhibit trading on in a VA or informal workout, being a concern for the bank, the IP and possibly also a creditors' committee.

\subsubsection{Loss of customer, supplier and employee goodwill}

Informal workouts and CVAs have the potential advantage that they can keep a company's financial distress hidden to some extent from suppliers and customers. Industry clustering will aid the visibility of distress. Moreover, workouts and CVAs depend for feasibility on good relationships with trade 
creditors. Customer and supplier goodwill are also important in liquidation as sale values will be affected, by being harder to maintain, as both customers and suppliers reflect negatively on the news that the IP has been appointed. The situation regarding employees will depend to some extent on how the process of bankruptcy is managed and how they see their prospects of job retention. Generally a workout or a CVA sends a more positive signal. Taking the option of liquidation runs the risk of damaging the prospects of the business as a going concern. Trade creditors may be resentful as they typically come away from a liquidation empty handed. In practice this problem does not appear to be particularly acute as most trade creditors are practical and will look to the prospect of good business in the future.

\subsubsection{Bargaining costs and creditor co-ordination}

Overall, as directors gain flexibility and control through greater informality, the price exacted by creditors increases. Higher support is needed as formality reduces, being effectively $100 \%$ from all classes of creditor in an informal workout, where an unsecured creditor owed as little as $£ 750$ can unilaterally petition for the winding up of the company. Administration and VA require $75 \%$ support from unsecured creditors together with $100 \%$ support from key secured creditors. This is quite a high threshold of support, yet is not viewed as being at an unrealistic level providing the company has a sound reconstruction plan and does have the desirable feature of being able to bind dissenting unsecured creditors into the plan.

Bargaining and co-ordination costs are low under liquidation, where creditors and directors have no say provided procedural rules are not infringed. The 
informal rehabilitation undertaken by banks as described in Franks and Sussman (2003) also avoids bargaining costs as banks act unilaterally, often to the detriment of other creditors.

Unsecured and trade creditors find that their influence increases as the informality of the re-organisation increases. Even small creditors can force a "holdout" situation if unanimous approval of rescue plans is needed. More generally, unsecured creditors play little active role in reconstruction.

\subsubsection{The right of the debtor to remain in possession.}

Here the issue hinges on whether or not incumbent management is an asset or a liability to the firm. Incompetent managers do remain in possession in UK CVAs (Cook et al. 2003), yet on the other hand managers are removed from control in and most other formal UK insolvency procedures, even though they may have valuable skills and experience to contribute. It is a weakness of the CVA that managers cannot be removed and are not subject to direction from the IP and this weakness contributes to inefficient continuation of the company and potentially also inefficient investment ex post. This can be remedied by either combining a CVA with an AO or drafting sufficient control clauses into the CVA to allow a supervisor effective veto powers.

From the secured creditor's point of view, a successful rescue could improve realisable values of secured assets as well as preserving a profitable business relationship. The secured creditor, however, has little incentive to take a gamble in cases of doubt, which stands in contrast to unsecured creditors who, like the directors of the company and equity holders face 
essentially a one-way bet with something to gain if the plan succeeds and nothing to lose if it does not. In this respect there is a bias in favour of premature liquidation.

\subsubsection{Freedom of action.}

The chances of effective rescue will be made more difficult where whoever is in effective control of the business lacks freedom of manoeuvre. This was part of the thinking behind the design of the AO in the UK, where swift and decisive action can be taken by the IP. The CVA contains flexibility at the outset as there is considerable freedom for directors and creditors to fashion a bespoke reconstruction plan. Managers also have unimpaired freedom of action within a CVA as long as they maintain their agreed schedule of payments into the creditors' fund. However, the powers available under the CVA, particularly the lack of ability to void contracts gives less room for manoeuvre than the AO. In this regard the CVA is even less favourable than straight liquidation where the obligations of the company cease. The same pertains in informal workouts which face the additional problem of maintaining $100 \%$ creditor support. 


\subsubsection{Ex ante costs}

Without significant evidence of "fraudulent" behaviour directors are not treated either particularly harshly or leniently in the UK system. The balance for the gambling effect is on the side of directors, equityholders and unsecured creditors wishing to prolong the life of the firm.

In general there is a perceived problem in the UK of firms delaying coming forward, thereby lessening the prospects of reconstruction and perhaps dissipating value in liquidation. The fact the debtor is allowed to remain in possession within a CVA appears to have had no influence on early filling. One of the potential triggers for a company filing for a CVA is a petition for winding up presented by an unsecured creditor. However the structure of insolvency law provides poor incentives for unsecured creditors who achieve low recoveries. Some creditors may rationalise petitioning for liquidation as a punishment for directors. A remedy for this would be to grant a petitioning creditor the incentive of more elevated status in the priority chain but this would be unattractive as it would create a perverse incentive in favour of asset runs and would distort the market for credit.

The delay effect is, however, much mitigated in the UK for SMEs due to the fact that their debt tends to be heavily concentrated in the form of bank debt. Franks and Sussman's (2003) evidence is that this concentration of debt does result in appropriate levels of monitoring by banks (Diamond 1984) and remedial action appears to be taken promptly. It is less certain that this mechanism works as effectively for large firms. 
Cook et al. (2003) find that only about 1 in 5 CVAs is successful to the extent that the firm fulfils its plan and continues to trade free of insolvency. They also report the general consensus that firms tend to carry on too long before addressing their problems. The implication is that some of these firms could be rescued if only they came forward sooner. Finally, it appears less true than it was that secured creditors will enforce premature liquidation, although there is a bias towards premature liquidation within AR given the receivers potential liability when trading on. Taken together the impression is that value is being destroyed in the main from liquidation or rescue not coming soon enough.

CVAs and informal workouts can lead to a loss of security rights (for example in a debt for equity swap) or security value as the asset is further run-down whilst attempting to trade profitably. Trade creditors could gain at the expense of secured creditors if they raise supply prices to recoup some of their debt, although there is no clear evidence of a systematic bias.

\subsection{Other factors influencing the choice of regime}

\subsubsection{Institutional factors and learning}

The rehabilitation efforts of banks outside formal insolvency have been the result of learning. One bank admitted it had been crude in its approach to insolvency before the 1990s and in particular had not properly understood how to get the most out of the CVA procedure. This is in terms not only of deciding which firms to place in a CVA and which not, but also ensuring that the plan was properly constructed and administered. There has also been an investment in learning required on the part of IPs too and the majority have 
judged this not to be worth the while. Attitudes of Crown creditors have also become more favourable to rescue over time.

This evidence regarding the response of banks to financial distress on SMEs stands in distinction to the evidence regarding how banks react to such distress in large firms, where the response is both more varied and in some cases more lenient (Asquith et al. 1994). Franks \& Sussman ascribe the lack of bank concessions towards SMEs to bureaucratisation in so far as those bank officers who deal with these cases lack the seniority to make such concessions. This contrasts with the case of large firms whose cases are dealt with by more senior bank officials and where there is evidence of debt forgiveness.

\subsubsection{Incentives of the IP}

Fee income relative to work done is an important consideration for the IP. This may be the case in the short-term but in the longer-term success relies on maintaining a good working relationship with major lenders and building up a respectable track record of successful cases (Flood and Skordaki, 1995). Thus IPs have an incentive to side with the bank's interests.

One view of "rescue" procedures is that they provide the opportunity for multiple fees as practitioner costs are often calculated on a time basis and the failure of a rescue package may well result in the same practitioner being appointed as liquidator to "mop up". Again, this ignores the reputational risk associated with failure and the growing set of guidelines and codes of conduct within the insolvency profession. Licensing of practitioners, introduced in the 1986 Insolvency Act, offers the opportunity to punish practitioners who abuse 
their position. Unfortunately, the dubious activities of some have reflected badly, albeit unfairly, on the procedure itself.

Cook et al. (2003) reveal that only a minority of IPs have experience of conducting VAs and this lack of familiarity is a barrier to their use. IPs feel more comfortable with procedures such as liquidation which they are fully conversant with. IPs are deterred from using VAs by other aspects of uncertainty such as the difficulty of committing to a proposal and the business plan which underpins it which may stretch several years into the future and which may be undermined by events. IPs also feel uneasy about their lack of control in VAs, where they have no powers to investigate or run the company and are essentially just there to collect monies owed and make disbursements. IPs have a strong professional norm that they should bring order and certainty to what is typically a confused and fraught situation. This brings a bias against the VA where too much is left to chance. A final important element of uncertainty, related to the others, is the difficulty of assessing the quality of the continuing directors in the short space of time between appointment and VA approval (typically two months).

\subsubsection{Future relationships}

With substantial debt recovery benefits it is questionable whether banks also value the private benefits of a continued business relationship that a rescue can offer. A successful rescue could provide a continued relationship for unsecured creditors too whilst a break-up will only provide the return of a portion of the debt. It should be acknowledged that in the UK debt recovery will include a Value Added Tax refund. Some trade debts are also insured but 
this can restrict credit terms granted (CMRC, 2005). There is more certainty but less reward in liquidation. An important influence on whether or not unsecured creditors will support a VA, for example, is whether or not they believe the directors have acted reasonably. The erosion of unsecured creditor confidence in the directors is a problem which tends to worsen the longer directors delay coming forward to address their problems.

Banks do appear to have become more mindful of the impact of their treatment of distressed firms on their reputation more generally. One influence on the declining use of administrative receivership has been fears that if banks were seen as riding roughshod, particularly over SMEs, then more radical legislation might be forthcoming diluting their rights. There may also be some concern to avoid an unfavourable image among potential SME customers, although the general lack of competition in this market speaks against this being a major influence.

\subsection{Conclusions}

The strong position of banks gives a partial explanation of why formal rescue mechanisms such as CVAs and Administration are not more widely used. Essentially banks have little need for them, being able to take effective action themselves to either put the distressed firm back on a stable financial footing or ultimately to have the company liquidated with the bank more often than not making a full recovery of debt. Only in a very small set of cases is the chosen insolvency procedure by a Debt Recovery Unit a CVA. 


\section{The choice in Sweden}

\subsection{Direct Costs}

Thorburn (2000) finds that direct costs of auctions are low, averaging $6.4 \%$ of pre-filing book value of assets for standard auctions and $2.5 \%$ for pre-pack auctions. Since there is an element of fixed cost, the percentage tends to fall the larger the firm. This is comparable with costs in Chapter 11. Thorburn concludes that cash auctions score well in terms of indirect costs since they have the advantage of speed. Recovery rates for creditors averaged $35 \%$ overall, $29 \%$ for piecemeal liquidations and $39 \%$ for going concern auctions, the latter comparable with Franks and Torous' (1994) evidence of $41 \%$ recoveries in their sample of Chapter 11 reorganizations.

As in the UK, banks enjoy a very strong position. Banks and directors of the company have an incentive to act in concert, typically to the detriment of the unsecured creditors.

\section{$5.2 \quad$ Indirect Costs}

\subsubsection{Ability to raise finance}

This issue is circumvented in the cash auction regime. Directors wishing to buy the business in a saleback will need usually to raise new finance. However, this may be seen as a market test of the case for the incumbent management retaining control of the assets. Within reconstruction, there is provision for debtor-in-possession financing with super-priority. In practice, 
the preference seems to be for the firm cutting its losses and making a fresh start.

\subsubsection{Ex post under- or over-investment}

The Swedish system is biased in favour of a quick sale (Stromberg 2000). On the one hand this economises on indirect costs which are related to time in bankruptcy. It may also represent a way of eradicating a debt overhang. On the other hand, unless new debt finance can be secured it may create a bias towards under-investment in that more of the call for new funds might have to come from equity.

The stay on creditor actions is effective both in bankruptcy auctions and reconstruction, therefore this aspect does not appear to be an influence on choice of regime. The lack of protection against secured creditors has been seen as powerful inhibitor against use of the Ackord (Thorburn 2000).

\subsubsection{Vulnerability to legal liability.}

From the Swedish director's perspective the disadvantages of bankruptcy are small in comparison to those in reconstruction whilst the advantages of bankruptcy clearly outweigh those available in any rescue scenario. Swedish directors appear to consider, far more, their immediate liability and their longer-term relationship with the Swedish banks than the retention of control of a troubled company. 


\subsubsection{Bargaining costs and creditor co-ordination}

Bargaining costs are minimal in bankruptcy which is a very quick and clean procedure (Thorburn 2000). Whilst there may in practice be some behind the scenes lobbying and perhaps negotiations for purchase, the procedure avoids the extensive courtroom costs associated with disputes over the value of assets and claims in Chapter 11. Less evidence is to hand on bargaining costs in reconstruction, although it is likely they will be slightly higher than in a cash auction.

\subsubsection{The right of the debtor to remain in possession.}

One feature of the Swedish auction system is that management is removed upon bankruptcy. This, it has been argued, may lead managers to gamble on risky projects in financial distress as they have nothing to lose and much to gain if the gamble succeeds. Eckbo and Thorburn (2003) argue that the opposite may be true, that CEOs of distressed firms may be more likely to invest conservatively in the hope of preserving a viable business which can be sold as a going concern in the auction and increasing their own chances of being re-hired by the auction winner as reward for their stewardship. In addition, managers, they suggest, will be concerned for their personal reputations and thus would be averse to taking actions likely to be regarded as reckless. They produce evidence consistent with these claims for a sample of Swedish firms. The authors find that there appears to be only a 
short delay in filing, on average 4 months, which speaks against the incentive of managers to put off the evil day of reckoning as long as possible.

\subsubsection{Flexibility.}

The rules governing bankruptcy auctions are not in themselves flexible, however in terms of the management of the business the procedure generates high levels of flexibility. Whoever wins the bid is essentially able to do with the business as they will. There appears to be less freedom of manoeuvre in setting up reconstructions.

\subsubsection{Distortion of choice through availability of subsidies}

Often cited as a major factor in favour of bankruptcy is the State Wage Guarantee. This provides a potentially large subsidy to a firm in bankruptcy not available to a firm in reconstruction. The existence of the Guarantee provides a large incentive to directors to opt for bankruptcy. The firm is able to trade on with the benefit of a subsidy and the proceeds are available to pay claims. The ability to trade on is an advantage for directors who rely to some extent on the continuation of the firm to maintain asset values and goodwill as they negotiate their own exit route from the bankruptcy with secured creditors.

Directors can also be personally liable for unpaid wages and taxes, delivering a powerful incentive to opt for bankruptcy rather than reconstruction The Wage Guarantee Act 1992 offers government funding to pay wages up to 
SEK100,000 $(£ 6,500)$ per employee in bankruptcy situations. The guarantee can be extended to allow continued trading during bankruptcy, also undermining some of the benefits of rescue.

The subsidy represented by the Wage Guarantee Act provides a strong incentive for all classes of creditor to support a bankruptcy, since these are guaranteed funds compared to the uncertain prospect of improved prospects in a reconstruction.

One potential disadvantage of cash auctions is the emphasis on a speedy sale as this might depress valuations. By contrast, reconstructions may avoid these costs.

\subsection{Ex ante costs}

The main aspect of the punishment effect for directors is where they fail to file for liquidation in line with the requirements of the balance sheet test. Evidence is that the law regarding mandatory filing for liquidation is almost always adhered to.

The delay effect situation in Sweden has some things in common with the UK. Debt among SMEs is concentrated in the bank which has a strong incentive to monitor. By contrast whilst unsecured creditors can petition for the bankruptcy of a company, with no minimum on the amount owed, few will benefit from such action. Unsecured creditors have no protection under insolvency legislation and little power to influence proceedings. Most unsecured creditors, traditionally the lowest priority level of creditors, receive little or no dividend in bankruptcy but have the potential to benefit more from 
reconstruction. An additional benefit of reconstruction and a strong factor against commencing bankruptcy action is the possibility of continued trading relationships with the debtor company, although this is mitigated by the high proportion of going concern sales in bankruptcy auctions.

Given the high propensity of incumbent management purchases in salebacks, directors of troubled companies have less incentive to gamble as they have the prospect of resolving the financial distress and retaining control of their business in the bankruptcy auction.

The Swedish regime appears to do well on inefficient reorganisations and liquidations. Thorburn's evidence suggests that the auction system does not give rise to a significant problem of premature liquidation given the high proportion of businesses which are preserved as going concerns. The very small numbers in reconstruction indicate there are few problems of inefficient reorganisation.

One important feature of sale-backs which Stromberg notes is that the bank and the equity holders do well in sale-backs, particularly in illiquid markets, thus violating some creditor priroity. The reason is that the assets can be bought back relatively cheaply relative to the true going concern value, which creates a surplus to be shared between the bank and shareholders. Thus although the proceeds of the auction are distributed in strict priority order, this benefit to the shareholders may produce de facto violations of absolute priority. This conclusion needs to be qualified in so far as many of the unsecured creditors will also have an interest in the business going forward (Stromberg 2000). It is not clear what ex ante effects if any these violations of priority give rise to regarding the availability and terms of trade credit. 


\subsection{Other factors influencing the choice of regime}

\subsubsection{Institutional factors and learning}

Swedish commercial culture appears to embrace the ability of directors to resurrect failed firms. In many cases directors are able to arrange new funding, shrug off old liabilities and maintain strong relationships with secured lenders (mainly banks). Although bankruptcy does not offer the super-priority for new debt it does match the virtual stay on creditor action found in reconstruction.

Reconstructions have been stifled and this, in itself, perpetuates their low incidence. A secured creditor would need to see massive benefits of a reconstruction and be able to trust an Insolvency Practitioner to deliver these before committing to such a plan. Lack of experience amongst the insolvency professionals only adds to the reasons to opt for bankruptcy in most cases.

The Swedish banking industry is typified by a few large institutions sharing the bulk of corporate business lending. Following the retrenchment and reassessment of risk of the early 1990's these institutions err on the side of caution and are not motivated by competitive pressures to take on additional risk.

\subsubsection{Incentives of the IP}

It is difficult to characterise the insolvency profession in Sweden. Most practitioners have a legal background and operate as part of major law firms. One exception, however, is the trade body Ackordscentralen. Practitioners 
here are legally trained but display a more commercial outlook. Experience suggests, however, that Ackordscentralen's managers deal with far more bankruptcy than reconstruction due to the lack of incentive for directors to call for help.

\subsubsection{Future relationships}

As is the case in the UK, it is trade creditors who perhaps have the most to gain from ongoing trading relationship. In this respect it is not clear that bankruptcy serves their interests badly as it has a good track record in preserving businesses.

To assume that insolvency practitioners merely wish to maximise fees earned is simplistic. They also wish to retain good working relationships with major lenders (banks) on whom they rely for introductions. This is a powerful argument for bankruptcy being sought in most cases.

\subsection{Conclusions}

The choice in Sweden is stark with little flexibility in both theory and practice. The low uptake of compositions cannot be explained by the logic that characterises the UK scene. In the UK directors can "buy" flexibility and control by obtaining high creditor acceptance for their plans and offering improved returns and continued trading relationships. In Sweden the strong position of secured creditors skews this choice despite the reconstruction legislation being creditor - friendly, especially where it gives super-priority for new lending (not available in the UK). 
The power of the secured creditor has been the focus of concern in Sweden but little has been done to amend legislation. To date proposals have been made by the Right of Priority Committee (1999) to amend The Right of Priority Act 1970 in order to create incentives for lenders to focus decisions on borrowers' ability to repay, rather than on security. The same proposals hope to encourage earlier filing for reorganisation. The proposals, still to be enacted, include the reduction of the Business Mortgage (akin to the floating charge in the UK) to $50 \%$ of all property; the abolition of priority for withholding taxes (VAT etc). Restriction on the amount that the government can claim in the stead of those employees it has paid through its wage guarantee is also mooted. These proposals, with the exception of the wage guarantee changes, show a similar approach to encouraging rescue by amending insolvency rules and rights of priority as in the UK. This research questions, however, the assumption that the legal framework is the key barrier to rescues in both countries.

\section{TABLE 4 ABOUT HERE}

\section{Conclusions}

The cost-benefit framework has allowed an objective overview of the insolvency choices in both UK and Sweden and permits general conclusions to be made. Table 4 contains a synoptic comparison of regimes (+ indicates the regime economises on a particular cost, - that it tends to exaggerate such costs and? implies some ambiguity). The preference for bankruptcy in 
Sweden is related to its decisive advantages in terms of indirect costs over reconstruction. It is quick, which itself economises on indirect costs, benefits from a substantial subsidy in terms of the State Wage Guarantee, avoids costly bargaining and provides and efficient and effective solution to the problems of valuing assets and determining in whose hands the assets find their highest valued use. Nevertheless, it is not simply the formal structure of the procedure which makes it work. Nothing in that formal structure guarantees that directors would be as willing to file as early as they do, nor that banks would be so willing to co-operate with them to the extent that more than half of them end up repurchasing their businesses. It is a more open question what ex ante costs the procedure gives rise to in terms of the cost and availability of credit.

Liquidation enjoys many of the same advantages in the UK, yet is less amenable to the preservation of the business as a going concern. In this regard the $\mathrm{AO}$ scores better given the wider powers of the administrator to trade on. What limited the traditional administrative receivership as a rescue vehicle was the poor incentives for the receiver to trade on given sole obligation to the appointing secured creditor and the potential liability for new debts. In terms of direct costs, the CVA compares favourably with other regimes, yet its key weaknesses in terms of indirect costs are manifest. Its average length of two years compared to weeks in a liquidation alone would drive a marked difference in indirect costs. Yet the position is worse. Underinvestment ex post is endemic given the lack of debtor-in-possession financing and the squeeze on working capital occasioned by a protracted 
period of commitment to paying into a creditors' fund while at the same time avoiding further arrears. The procedure also has critical limitations in terms of a lack of powers to either change or direct management. In this respect it is inferior to every other type of regime. What was thought at the inception of the Insolvency Act 1986 to be one of the great virtues of this debtor-inpossession regime, that it would encourage early filing, has proved to be a mirage. The ex ante costs of delay and gambling effects remain substantial and unmitigated. In this respect, the legislation has singularly failed to appreciate the psychology of directors of distressed companies (see Milman and Cook 2002).

It is in the lack of control and the length of the procedure that it is most evident that the framework of legislation has been found wanting in terms of failing to understand the incentives and motives of insolvency practitioners. To them being supervisor of a CVA places them in an invidious position of having responsibility without authority. This coupled with the inherent uncertainties of a drawn out procedure - and one with which only a small minority if IPs to this day have any experience of - is a substantial deterrent to its use by professionals who are strongly motivated by their norms to bring order and certainty to any insolvency scenario. The framework of legislation and policy debate, at least in the UK, does not acknowledge the apparently substantial role of banks in informal restructuring of SMEs. More could be done to promote and facilitate this work, particularly given the superior monitoring ability and incentives of banks. 
In many of these respects the new style $A O$ regime ushered in by the Enterprise Act 2002 holds promise. The direct costs of the regime have been lowered by a much reduced role for the court. It still retains the wide powers for the administrator to trade on and to tackle the problem of weak management and is also more favourable to "pre-pack" sales of assets to refinanced incumbent management.

What, then, are the key strengths and weaknesses of the UK and Swedish bankruptcy regimes? In both the UK and Sweden the powerful position of banks means that the insolvency regime is efficient in preserving businesses, if not companies. There is a great deal of flexibility inherent in the UK system, created in part by the wider menu of bankruptcy regimes on offer. This flexibility offers the chance to tailor the chosen regime more closely to the specific circumstances of the insolvent company. Herein also lies a potential weakness in that powerful creditors may bring about a collectively sub-optimal resolution by forcing the company into a regime which bests serves their interests or by extracting concession under the threat to do so. The ability of banks always to enforce administrative receivership is an example, but one now largely foreclosed by the Enterprise Act 2002. The key advantages of the Swedish cash auction system are that it is quick, efficient and subjects the valuation and control of assets to a market test. Its main disadvantages are that it appears to be prejudicial to the interests of unsecured creditors. It is also very strongly biased against corporate reconstruction. 
What does this evidence imply about the utility of the government's attempts to use insolvency law reform to combat the fear of failure and so promote entrepreneurship? Firstly, the low numbers of CVAs in the UK and reconstructions in Sweden imply that its influence may be slight. Nevertheless in the case of CVAs, the procedure does allow the problems of insolvent small firms to be addressed, resulting with good rates of business survival and orderly wind-up in those cases where the company cannot be saved. Thus CVAs can help avoid failure or, if not, mitigate its effects. To that extent, the CVA probably deserves to be more strongly promoted. One aspect which is particularly important is that CVAs pay better returns to trade creditors than other types of regime, thus helping to avoid a domino effect where the failure of one company can lead to the failure of its suppliers. Nevertheless, policy makers have to be realistic. The CVA is not, nor could it be, a panacea.

Whilst the focus of legislators in both countries is on the detail of the various measures in place to encourage debtor reconstruction and rescue the legal framework itself only provides opportunities - it is the key motivations and economic costs and benefits of stakeholders that dictate whether a rescue is initiated. Legislators need to bear in mind that social institutions and cultural attitudes tend to change slowly, despite changes in the law (North 1990). One issue policymakers still need to address satisfactorily is how to get directors of failing companies to come forward sooner. Doing so will increase the chances of a successful turnaround and limit the extent to which directors 
dissipate their personal wealth in what may prove to be a doomed attempt to keep a company afloat. This, however, is likely to prove a tough nut to crack.

The paper suggests a number of directions for further research. A fundamental problem in choice of regime is how to tell apart firms with genuine prospects from those which are not viable. More needs to be known about turnaround of SMEs. Little appears to be known about the ex ante effects of different bankruptcy regimes on the terms and availability of trade credit. Mindful of the prime motivation of the global trend of bankruptcy reform, to encourage entrepreneurship, we need to better understand whether unsecured creditors and entrepreneurship more generally might be better served by attempting rehabilitation as opposed to "phoenixism". More research is warranted into the extent of underpricing in cash auctions. The debate about promoting corporate rescue is predicted on the assumption that there is a widespread problem of viable businesses being broken up. A sober assessment is needed as to how extensive this problem really is to provide legislators with a realistic assessment of what could be achieved and whether, indeed, any further action is really necessary. Finally, a better understanding is required of the decision processes which lead both to filing for bankruptcy and how the choice is actually made to place a firm in one regime or another. This will help in framing legislation in such a way which will genuinely influence such choices. 


\section{References}

Asquith, P., Gertner, R. and Scharfstein, D. (1994). Anatomy of Financial Distress: An

Example of Junk-Bond Issuers, The Quarterly Journal of Economics, vol. 109, pp. 625-658.

Audretsch, D.B. (2002). Entrepreneurship: A Survey of the Literature. Brussels: Commission of the European Communities.

Baird, D. (1986). The Uneasy Case for Corporate Reorganizations. Journal of Legal Studies, vol. 15, pp. 127-147.

Belcher, A, (1997), Corporate Rescue: A Conceptual Approach to Insolvency Law, Sweet and Maxwell, London.

Bergström, C, Eisenberg, T and Sundgren, S, (2004), On the design of Efficient Priority Rules for Secured Creditors: Empirical evidence from a change in law, European Journal of Law \& Economics, Vol: 18, pp $273-297$.

Bolton, P. and Scharfstein, D.S. (1996). Optimal Debt Structure and the Number of Creditors. Journal of Political Economy, vol. 104, pp. 1-25.

Bowman, E.H. (1982). Risk Seeking by Troubled Firms. Sloan Management Review, Summer, pp. 33-42.

Bowman, E.H. (1980). A Risk/Return Paradox for Strategic Management. Sloan Management Review, Spring, pp. 17-30. 
Brown, D.T. (1989) Claimholder Incentive Conflicts in Reorganization: The Role of Bankruptcy Law. Review of Financial Studies, vol. 2, pp. 109-123.

Chatterjee, S., Dhillon, U.S. and Ramirez, G.G. (1996) Resolution of Financial Distress: Debt Restructurings Via Chapter 11, Prepackaged Bankruptcies and Workouts. Financial Management, vol. 25, pp. 5-18.

Chen, Y., Weston, J.F. and Altman, E.I. (1995) Financial Distress and Restructuring Models. Financial Management, vol. 24, pp. 57-76.

Claessens, S. and Klapper, L.F. (2002). Bankruptcy around the World: Explanations of Its Relative Use. World Bank Policy Research Working Paper 2865, July.

Cook, G., Pandit, N., Milman, D., and Mason, C. (2003) Small Firm Rescue: A Multi-Method Empirical Study of Company Voluntary Arrangements. London: ICAEW.

Cook, G.A.S. and Pond K, (2001 (b)), Swedish Corporate Rescue, Recovery, London, September.

Credit Management Research Centre, (2005), Credit Policy in the UK Economy: Prepared for the Small Business Service, April.

Diamond, D.W. (1984). Financial Intermediation and Delegated Monitoring. Review of Economic Studies, vol. 51, pp. 393-414.

Easterbrook, F.H. (1990) Is Corporate Bankruptcy Efficient? Journal of Financial Economics, vol. 27, pp. 411-417.

Eckbo, B.E. and Thorburn, K.S. (2003). Control Benefits and CEO Discipline in Automatic Bankruptcy Auctions. Journal of Financial Economics, vol. 69, pp. 227-258. 
European Commission (2004). Action Plan: The European Agenda for Entrepreneurship. $\operatorname{COM}(2004) 70$ final. Commission of the European Communities, Brussels.

European Commission (2003). Creating an Entrepreneurial Europe. The Activities of the European Union for Small and Medium-Sized Enterprises. Commission Staff Working Paper SEC(2003) 58.

European Commission (2000). Towards Enterprise Europe. Work Programme for Enterprise Policy 2000-2005. Commission Staff Working Paper, SEC(2000) 771.

Flood J \& Skordaki E, (1995), Insolvency Practitioners and Big Corporate Insolvencies, Chartered Association of Certified Accountants, London, 1898291535

Franks, J.R., Nyborg, K.G. and Torous, W.N. (1996). A Comparison of US, UK and German Insolvency Codes. Financial Management, vol. 25, pp. 86-101.

Franks, J.R. \& Sussman, O. (2003). Financial Distress and Bank Restructuring of Small-toMedium Size UK Companies. Centre for Economic Policy Research Discussion Paper 3915.

Franks, J.R. and Torous, W.N. (1994). A Comparison of Financial Recontracting in Distressed Exchanges and Chapter 11 Reorganizations. Journal of Financial Economics, vol. 35, pp. 349-370.

Franks, J.R. and W.N. Torous, (1992), Lessons from a comparison of US and UK insolvency codes, Oxford Review of Economic Policy, vol. 8, pp. 70-82.

Gertner, R. and Scharfstein, D. (1991) A Theory of Workouts and the Effects of Reorganization Law. Journal of Finance, vol. 46, pp. 1189-1222. 
Gilson, S.C. (1997). Transaction Costs and Capital Structure Choice: Evidence from Financially Distressed Firms. Journal of Finance, vol. 52, pp. 161-196.

Gilson, S.C, (1996), Managing default: some evidence on how firms choose between workouts and chapter 11, in Weiss, L.A. and J.S. Bhandari, (1996), Corporate bankruptcy: Economic and Legal Perspectives, Cambridge University Press, Cambridge, pp 308-321.

Gilson, S.C., K. John and L. Lang, (1990), Troubled debt restructurings: An empirical study of private reorganization of firms in default, Journal of Financial Economics, vol. 27, pp 315-333.

Hamilton R, Howcroft JB, Liu Z and Pond K, (1997), Back from the Dead: Survival Potential in Administrative Receivership, Insolvency Law \& Practice, Vol 13, No 3, pp. 78 - 81.

Hansen, R.G. and Thomas, R.S. (1998). Auctions in Bankruptcy: Theoretical Analysis and Practical Guidance. International Review of Law and Economics, vol. 18, pp. 159-185.

Hart, O. and Moore, J. (1998). Default and Renegotiation: A Dynamic Model of Debt. The Quarterly Journal of Economics, vol. 113, pp 1-41.

Hotchkiss, E.S. (1995). Postbankruptcy Performance and Management Turnover. Journal of Finance, vol 50, pp. 3-21.

International Monetary Fund (1999). Orderly \& Effective Insolvency Procedures. ?:IMF.

Kahl, M. (2002) Economic Distress, Financial Distress and Dynamic Liquidation. The Journal of Finance, vol 57, pp. 135-168.

Kahneman, D and Tversky, A. (1979). Prospect Theory: An Analysis of Decision under Risk. Econometrica, vol. , pp. 
Kaiser, K.M.J, (1996), European bankruptcy laws: implications for corporations facing financial distress, Financial Management, vol. 25, pp 67-85.

Keasey, K. and R. Watson (1994). The 1986 U.K. Insolvency and Company Directors Disqualification Acts and their Impacts upon Small Firm Financing Decisions.' Small Business Economics, vol. 6, pp. 257-266.

Kent, P., (1994), The London Approach, Bank of England Quarterly Bulletin, No 110.

Milman, D. and Cook, G. (2002) Managing distressed companies: adapting to a new legal culture. Managerial Finance

Mooradian, R.M. (1994) The Effect of Bankruptcy Protection on Investment: Chapter 11 as a Screening Device. Journal of Finance, vol. 49, pp. 1403-1430.

Nayak, A. and S. Greenfield (1994). The Use of Management Accounting Information for Managing Micro Businesses. In A. Hughes and D.J. Storey (Eds.) Finance and the Small Firm. London: Routledge.

North, D.C. (1990). Institutions, Institutional Change and Economic Performance. Cambridge: Cambridge University Press.

OECD (1998). Fostering Entrepreneurship. Paris: Organisation for Economic Co-operation and Development.

Piesse, J. and D. Wood, (1992)., Issues in Assessing MDA Models of Corporate Failure: A Research Note, British Accounting Review, (24), pp. 33-42.

Persson, A.H, (2003). Commercial and Economic Law - Sweden, Kluwer Law International, 67-77. 
Rights of Priority Committee, (1999), Nya förmånsrättsregler, SOU 1999:1.

R3, (2004), 12th Survey, Association of Business Recovery Professionals, London. (accessed at http://www.r3.org.uk/)

R3 (2000). $9^{\text {th }}$ Survey of Company Insolvency. London: R3.

SPI (1999). $8^{\text {th }}$ Survey of Company Insolvency. London: SPI.

SPI (1997). $7^{\text {th }}$ Survey of Company Insolvency. London: SPI.

SPI (1996a). $6^{\text {th }}$ Survey of Company Insolvency. London: SPI.

SPI (1996b). $5^{\text {th }}$ Survey of Company Insolvency. London: SPI.

Senbet, L.W. and J.K. Seward, (1995), Financial distress, bankruptcy and reorganization, In R. Jarrow, V. Maksimovic and W.T. Ziemba (eds). Handbooks in Operations Research and Management Science, vol. 9, pp921-961.

Stromberg, P. (2000). Conflicts of Interest and Market Illiquidity in Bankruptcy Auctions: Theory and Tests. Journal of Finance, vol. 55, pp. 2641-2692.

Thorburn K.S, (2000), Bankruptcy auctions: Costs, debt recovery, and firm survival, Journal of Financial Economics, Vol 58, Iss 3, Amsterdam, p.337.

Vickrey, W. (1961). Counterspeculation, Auctions and Competitive Sealed Bid Tenders. Journal of Finance, vol. 16, pp. 8-37.

Webb, D.C. (1991). An Economic Evaluation of Insolvency Procedures in the United Kingdom: Does the 1986 Insolvency Act Satisfy the Creditors' Bargain? Oxford Economic Papers, vol. 43, pp. 139-157.

Weiss, L.A. (1990). Bankruptcy Resolution. Direct Costs and Violation of Priority of Claims. Journal of Financial Economics, vol. 27, pp. 285-314. 
Weiss, L.A. and K.H. Wruck (1998). 'Information Problems, Conflicts of Interests and Asset Stripping: Chapter 11's Failure in the Case of Eastern Airlines.' Journal of Financial Economics, vol. 48, pp. 55-97.

Wheatley, D.A, (1983), Intensive Care - Life Saving Task for the Profession, Accountancy, Vol. 94, No. 1080, August.

White, M.J. (1989) The Corporate Bankruptcy Decision. Journal of Economic Perspectives., vol. 3, pp. 129-151.

Wruck, K.H. (1990). Financial Distress, Reorganisation and Organizational Efficiency. Journal of Financial Economics, vol. 27, pp. 419-444. 
Tables

Table 1 Alternative insolvency regimes in the UK and Sweden

\begin{tabular}{|l|l|l|}
\hline & UK & Sweden \\
\hline Rescue & $\bullet$ Corporate Voluntary & $\bullet$ Reconstruction \\
& $\bullet$ Arrangement & $\bullet$ Ackord \\
& $\bullet$ Administration & \\
& $\bullet$ Receivership & \\
\hline Liquidation & $\bullet$ Compulsory Liquidation & $\bullet$ Bankruptcy \\
& $\bullet$ Voluntary Liquidation & $\bullet$ Liquidation \\
\hline
\end{tabular}


Table 2 Corporate Insolvencies in England \& Wales 1995-2004

\begin{tabular}{|c|c|c|c|c|c|c|c|}
\hline Type of Insolvency ${ }^{a}$ & 1995 & 1997 & 1999 & 2000 & 2001 & 2003 & 2004 \\
\hline Compulsory Liquidations & 5519 & 4735 & 5209 & 4925 & 4675 & 5234 & 4584 \\
\hline Creditors' & 9017 & 7875 & 9071 & 9392 & 1029 & 8950 & 7608 \\
\hline liquidations & & & & & 7 & & \\
\hline Administrative & 3266 & 1837 & 1618 & 1595 & 1914 & 1261 & 864 \\
\hline Receiverships & & & & & & & \\
\hline $\begin{array}{l}\text { Administration Orders } \\
\text { (inc. AO under Enterprise. } \\
\text { Act 2002) }\end{array}$ & 163 & 196 & 440 & 438 & 698 & $\begin{array}{l}726 \\
(247)\end{array}$ & $\begin{array}{l}458 \\
(457)\end{array}$ \\
\hline Voluntary Arrangements & 372 & 629 & 475 & 557 & 597 & 726 & 597 \\
\hline
\end{tabular}

Source: DTI Statistics Directorate, 2005

${ }^{a}$ some companies may be subject to more than one procedure

${ }^{\mathrm{b}}$ Enterprise Act appointments only after 15 September 2003. 
Table $3 \quad$ Corporate Insolvencies in Sweden 1995 - 2004

\begin{tabular}{llllllll}
\hline Type of Insolvency & 1995 & 1997 & 1999 & 2000 & 2001 & 2003 & 2004
\end{tabular}

\begin{tabular}{llllllll}
\hline Bankruptcy & 12655 & 11044 & 7362 & 6733 & 7433 & 8237 & 7649
\end{tabular}

Compositions $^{\mathrm{a}}$ (Ackord) $119 \quad 40$

$\begin{array}{lllllll}\text { Corporate Reconstructions }^{b} & 191 & 109 & 50 & 31 & 35 & 47\end{array}$

Source: Institutet för Tillväxtpolitiska Studier, 2005.

a Under Composition Act 1970

${ }^{\mathrm{b}}$ Under Business Reconstruction Act 1996 (Effective 1 September 1996) 
Table 4. Synoptic Comparison of Costs in Each Regime

\begin{tabular}{|c|c|c|c|c|c|c|c|c|c|c|c|}
\hline Regime Cost & $\begin{array}{l}\text { Direct } \\
\text { costs }\end{array}$ & $\begin{array}{ll}\text { Ability to } \\
\text { raise } \\
\text { finance }\end{array}$ & $\begin{array}{l}\text { Under- or } \\
\text { over- } \\
\text { investment }\end{array}$ & $\begin{array}{ll}\text { Stay on } \\
\text { actions }\end{array}$ & $\begin{array}{l}\text { Legal } \\
\text { liability if } \\
\text { trading on }\end{array}$ & $\begin{array}{l}\text { Loss of } \\
\text { goodwill }\end{array}$ & $\begin{array}{l}\text { Bargaining } \\
\text { costs }\end{array}$ & $\begin{array}{l}\text { Ability to } \\
\text { remove poor } \\
\text { management }\end{array}$ & $\begin{array}{l}\text { Freedom } \\
\text { of action }\end{array}$ & $\begin{array}{l}\text { Subsidy } \\
\text { distortions }\end{array}$ & $\begin{array}{l}\text { Ex ante } \\
\text { costs }\end{array}$ \\
\hline \multicolumn{12}{|l|}{ UK } \\
\hline Liquidation & ++ & $?$ & $\begin{array}{l}- \\
\text { under- } \\
\text { investment }\end{array}$ & $\begin{array}{l}? \\
\text { too late }\end{array}$ & - & $\begin{array}{l}-? \\
\text { poor } \\
\text { signal but } \\
\text { soon } \\
\text { complete }\end{array}$ & ++ & ++ & $?$ & ++ & $\begin{array}{l}\text { - } \\
\text { delay and } \\
\text { gambling } \\
\text { effects }\end{array}$ \\
\hline $\begin{array}{l}\text { Administrative } \\
\text { Receivership }\end{array}$ & ++ & $?$ & $\begin{array}{l}- \\
\text { under- } \\
\text { investment }\end{array}$ & $\begin{array}{l}? \\
\text { too late }\end{array}$ & -- & $\begin{array}{l}-? \\
\text { poor } \\
\text { signal but } \\
\text { soon } \\
\text { complete }\end{array}$ & ++ & ++ & + & ++ & $\begin{array}{l}\text { - } \\
\text { delay and } \\
\text { gambling } \\
\text { effects }\end{array}$ \\
\hline $\begin{array}{lr}\text { Informal } & \text { Bank } \\
\text { Workout } & \text { for } \\
\text { SMEs } & \\
\end{array}$ & ++ & $?$ & $\begin{array}{l}+ \\
\text { bank takes } \\
\text { informed } \\
\text { decision }\end{array}$ & $\begin{array}{l}- \\
\text { little point } \\
\text { in a } \\
\text { petition }\end{array}$ & $\begin{array}{l}? \\
\text { potential } \\
\text { liability }\end{array}$ & + & + & + & ++ & ++ & $\begin{array}{l}? \\
\text { effect on } \\
\text { trade } \\
\text { credit }\end{array}$ \\
\hline CVA & + & -- & + & + & + & ++ & $?$ & -- & + & ++ & $?$ \\
\hline Administration & $?$ & + & + & ++ & $?$ & + & $?$ & + & ++ & ++ & $?$ \\
\hline \multicolumn{12}{|l|}{ Sweden } \\
\hline Liquidation & ++ & $?$ & + & $\begin{array}{l}? \\
\text { too late }\end{array}$ & + & + & ++ & ++ & + & +++ & $?$ \\
\hline Reconstruction & $?$ & $?$ & $?$ & + & + & + & $?$ & $?$ & + & --- & $?$ \\
\hline
\end{tabular}




\section{Footnotes:}

${ }^{\mathrm{i}}$ A maximum of 12 months.

ii "Small companies" should meet two of the three criteria of: Turnover below $£ 2.8 \mathrm{~m}$., Balance Sheet totals below $£ 1.4 \mathrm{~m}$. and fewer than 50 employees.

${ }^{\text {iii }}$ Floating charges are non-possessory security interests in the uncharged assets of the debtor company.

iv The "prescribed part" of floating charge realisations available to unsecured creditors has a $£ 10,000$ minimum value, a $£ 600,000$ maximum value and is calculated on the scale of $50 \%$ of the first $£ 10,000$ and $20 \%$ of any remainder.

${ }^{\vee}$ Prior to 15 September 2003 Crown creditors (mainly uncollected employment tax (PAYE) and purchase tax (VAT) had preferential status and ranked above floating charge holders.

${ }^{v i}$ UK insolvency law enshrines two definitions of insolvency, the Balance Sheet test and the Liquidity test.

vii He notes that this is a dynamic problem given high recidivism rates of firms which have been in chapter 11. 